\title{
CONTAMINATION OF SELECTED COMPONENTS OF ENVIRONMENT IN THE MIDDLE SPIŠ REGION (SLOVAK REPUBLIC)
}

DOI: http://dx.doi.org/10.18509/GBP.2015.06

UDC: 504.5:546.4/.8(437.6)

\author{
Dr. Vladimir Cech, \\ Prof. Eva Michaeli, \\ Dr. Juliana Krokusova, \\ Dr. Monika Ivanova \\ Faculty of Humanities and Natural Sciences, University of Prešov, Slovakia
}

\begin{abstract}
Region of Middle Spiš is among the most environmentally burdened areas in Slovakia. It is the result of a long tradition of industry and mining in the region. Rich deposits of copper and iron ores in the Slovak Ore Mountains necessitated the expansion of mining and metallurgical activities in the region of Middle Spiš. Mining activity and the bulk of the industrial activity in the area was closed early 90s of the 20th century. Centuries-long mining and industrial activities had and continues to have negative effects on all components of the environment, which is among the environmentally degraded and heavily burdened. The paper deals with the analysis of the quality and the environmental load of soils and water impacts of mining and industrial activities. The main aim of the articles the analysis of heavy metals of the sample in the soils and water and their comparison with the results during active mining and industrial operation. Our aim is to try to point out on the continue contamination of selected elements of the environment.
\end{abstract}

Keywords: contamination, heavy metals, soil samples, water samples

\section{INTRODUCTION}

The Middle Spiš is the part of historical region of Spiš. From an administrative point of view belongs currently into the Region of Košice into the districts Spišská Nová Ves and Gelnica. According of the Environmental regionalization of Slovak Republic [2010] belongs into the Rudnianský okrsok (circuit) in which is the considerably damaged environment (Fig. 1). In this area live 87,000 inhabitants in 21 settlements of which are 3 towns. The territory occupies of $364 \mathrm{~km}^{2}$. The area of middle Spiš with two main industrial centers Rudňany and Krompachy is contaminated with two processes, mining operations and metallurgical plants (processing the iron ore but in the past decades mainly copper ore and mercury-tetrahedrite) for centuries. In the research territory are also old environmental burdens after mining and after engineering industry in Prakovce, Slovinky and Gelnica. The area of Middle Spiš in Slovakia is rather on the traditional mining area. There have been rich mineral reserves, especially copper, iron and mercury ore. In the past there was performed intensive mining and industrial activities. In the region began the attenuation mining and industrial processing of raw materials after 1989. The unprofitable mining (underground) and small stocks of raw materials resulted to the closure of mine and industrial activities at the Rudňany and Slovinky in years 1992 1993. Mining and industrial activity had a major negative influence on environment in this area on one side (by emission the pollutants to water, soils, air and also influence on the health of inhabitants) but on the other side stopping these activities had negative 
influence to the population (loss of employment, emergence of social uncertainty for most families) [7]. More than fifteen years after the ending the exploitation of raw materials, we can still watch the negative effects of exploitation, not only in terms of the environment, but also from the aspect of municipalities in which are the mining directly touches every spheres of life. Impact of mining activities on the landscape and on its elements is a complex problem. Mining of the raw materials it leaves largely irreversible changes in the mining basement and also on the earth surface. On the one site on the earth surface created nearly irreversible changes of relief were created mining anthropogenic forms e. g. cave-ins, accumulative mining forms - the heaps and tailing ponds (sludge beds), whose reclamation is very difficult (sometimes impossible) and in the basement of mining are represented by shafts, galleries, pit and various corridors in undermined territory. On the other site was created contamination of all components of the landscape by heavy metals [1], [2], [5], [11]. In the surroundings of Rudňany are the high levels of heavy metals in water and soils- $\mathrm{Hg}$-mercury, $\mathrm{Cu}$-cooper, $\mathrm{Cd}$-cadmium, $\mathrm{Pb}$ - lead, $\mathrm{Sb}$ - antimony. According to an estimate only for 60 years of operation of old factory for the heat treatment of ores were released into the atmosphere a several one thousand tons of $\mathrm{Hg}$ predominantly in metallic form and from the new factory escaped into the atmosphere and then has undergone into the soils approximately 142 tons of metallic $\mathrm{Hg}$. The surroundings of Krompachy and Slovinky were contaminated with heavy metals: As arsenic, $\mathrm{Cu}$ - cooper and $\mathrm{Zn}$.-zinc. The main sources of of environmental contamination are manufacturing simplex "Iron Ore mines" in Rudňany (roaster of ore, the mill of ore, production plant of mercury, flotation of ore, pond - sludge bed), "Kovohuty" Krompachy and mines in Slovinky and Smolník. The industrial and mine komplex contaminates the air, water and soils to the heavy metals ( $\mathrm{Hg}$ - mercury, As - arsenic, $\mathrm{Pb}$ - lead, $\mathrm{Cd}$ cadmium) and the sulfur oxides (metalliferous ores are sulfides). The dispersion of contaminants (emissions) in Rudňany from aspect of the distance the factory is small, given the level of factory chimneys, only a few km. In Krompachy the emissions of $\mathrm{SO}_{2}$ and As spread over a long distance (chimney height is here 200 meters) and damaged forests in the surrounding mountains. Those industrial factories have issued about 35,000 tons of emissions per year into the year 1985 (the area is constantly at risk).

\section{RESEARCH TERRITORY IN REGION OF MIDDLE SPIŠ}

The points of the collection of soil and water samples we have placed in a homogeneous area in the basin Slovinský potok (brook), and we used those sites where sampling was carried out at the time of active operation of mining and industrial plants in year 1985. In the basin of Slovinský potok (brook) there are the remnants of mining and industrial activity. In the basin located artificial forms of relief which were created by human activity. This is e.g. cave-ins, accumulative mining forms - the heap and tailing ponds (sludge beds) etc. which remain in the country for decades and their reclamation is timeconsuming and costly. Often contain hazardous waste with a high content of heavy metals [3], [4], [10]. 


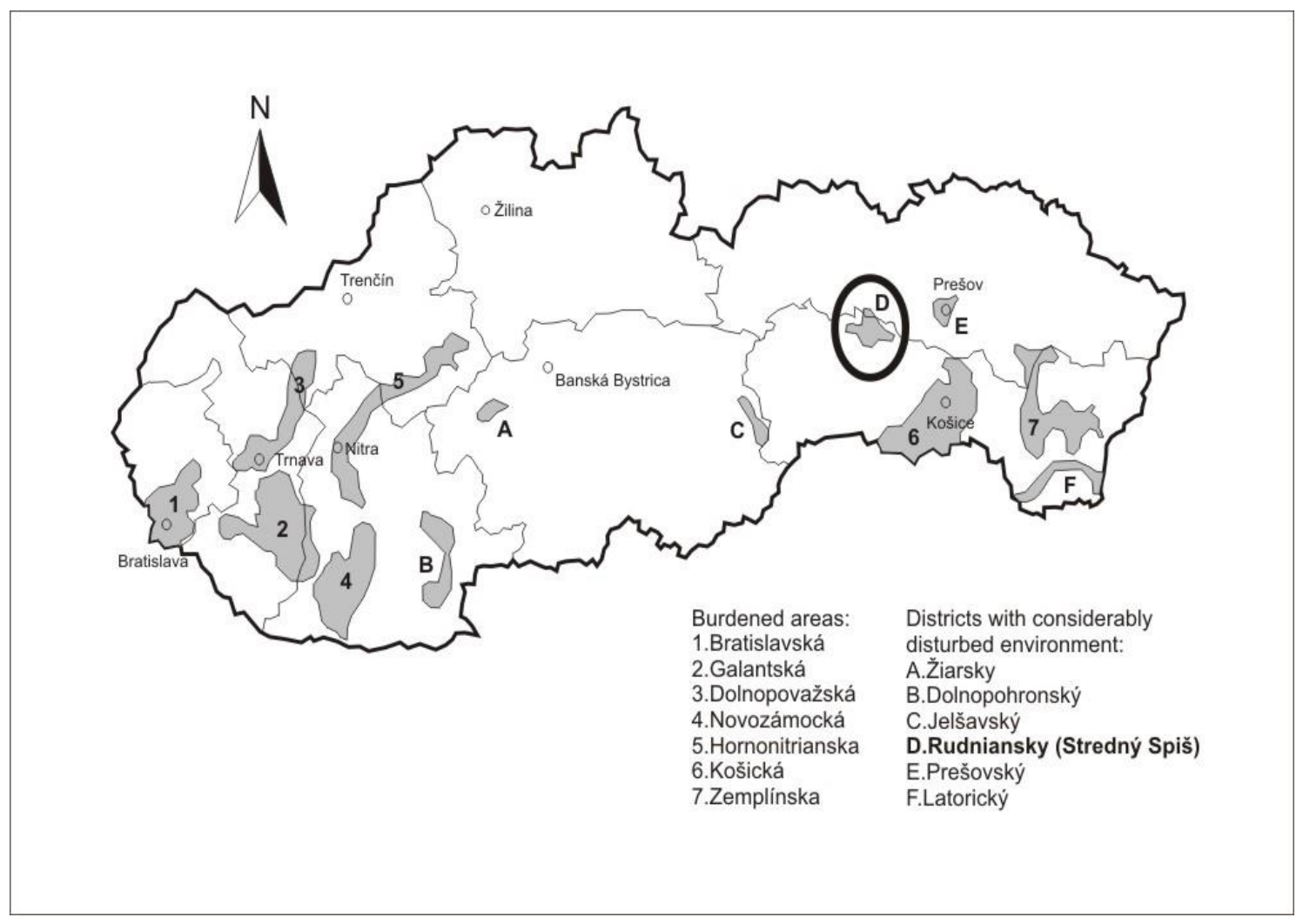

Figure 1 Burdened regions and circuits with considerably disturbed environment in the Slovak Republic [9].

\section{MATERIALS AND METHODS}

In the basin of Slovinský potok (brook) we conducted sampling of soil and water samples on the 10 localities (5 samples of soils, 5 samples of water, Fig. 2). The soil sample SSL 1 on the body of sludge beds Slovinky, sample SSL5 on the industrial heap Halna Krompachy. The samples SSL2, SSL3 and SSL4 we collected from the localities permanent grassland in cadastral territory Slovinky and Krompachy. The water sample of WSL1 was collected at the site from the mine water inflow into the Slovinský potok (brook), the water sample WSL2 originates from the place under reservoir for water treatment plant in Slovinky from the heap which is located on the bank of the brook, the sample WSL3 upper flow Slovinský potok (brook) above reservoir for water treatment, sample WSL4 built-up area (Sídlisko Mier) where flowing the stream in an artificial cobblestone riverbed, and WSL5 sample were taken at the point of confluence the Sloviský potok (brook) with the Hornád river. Samples were taken several times during the summer of 2010 and, 2011. In the soils and water samples are been found to contain heavy metals $\mathrm{Cu}, \mathrm{As}, \mathrm{Cd}, \mathrm{Pb}, \mathrm{Ni}, \mathrm{Cr}, \mathrm{Co}, \mathrm{Fe}$. The analysis was performed in an Accredited of test laboratory of the State Geological Institute of Dionýz Štúr in Spišská Nová Ves. In the aqueous samples was used the method AES-ICP: atomic emission spectrometry with inductively coupled plasma and AAS: Atomic Absorption Spectrometry. In the case of soil sampling method was used RFS: röntgen fluorescent spectrometry and AAS: Atomic Absorption Spectrometry. The results for the years 2010 and 2011 we compared with the results of year 1985, when in that area was mining and production. 


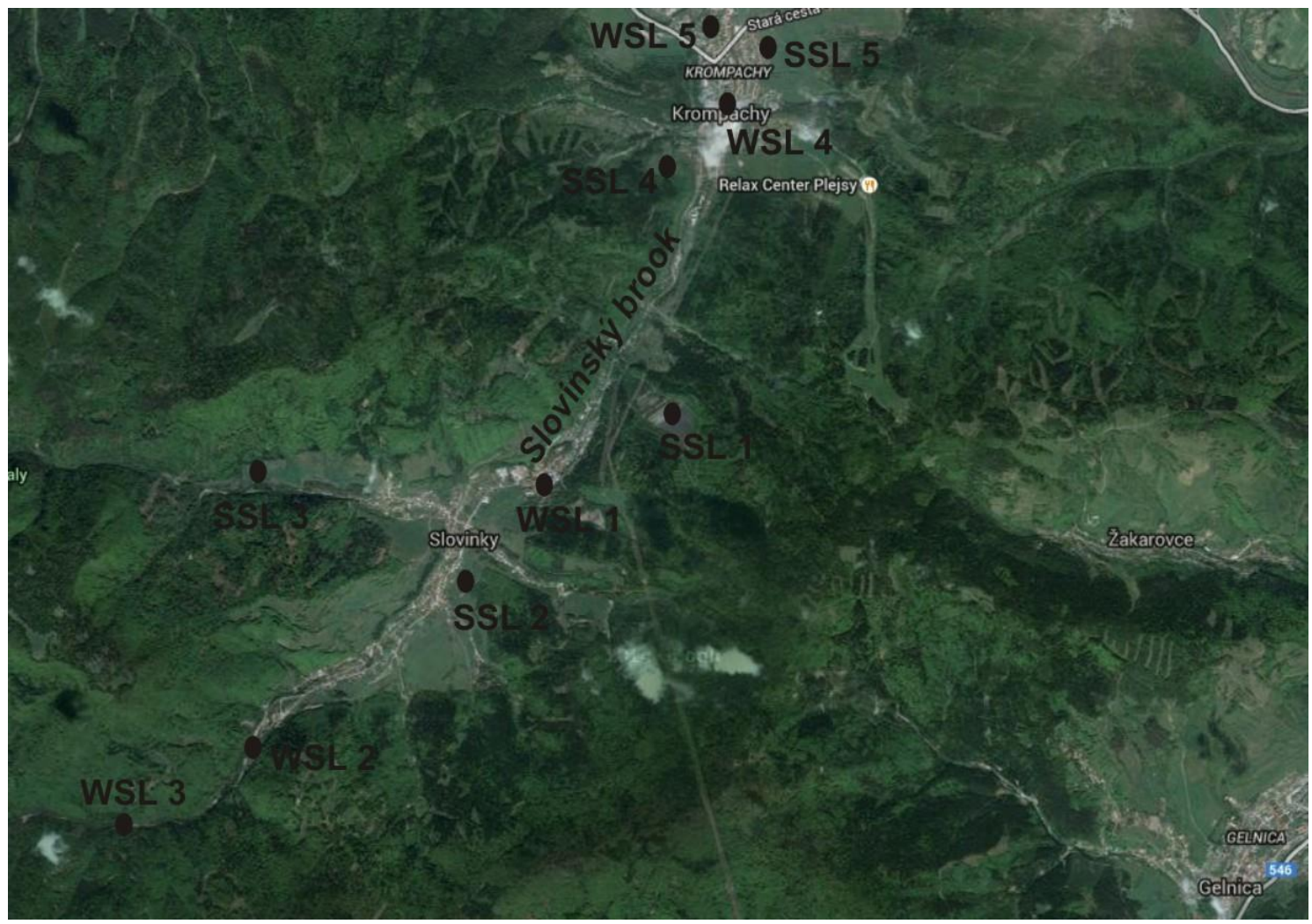

Figure 2. Localization of the water samples (WSL) and soil samples (SSL) in the basin of Slovinský potok (brook) 2010 and 2011

\section{RESULTS AND DISCUSSION}

In the case of water samples (Table 1) are most exceeded the limit value for WSL1, we also anticipated as these are place inflow of mine water flowing from the mine, whose entrance is about 10 meters above the Slovinský potok (brook). The most significant are the limit values are exceeded in As, in the all three years (1985, 2010, 2011). Limit values exceeds also the $\mathrm{Pb}$ in 2011, and $\mathrm{Cu}$ in the all three years. Values of other heavy metals are below the limit values. For sample WSL2 limit value was exceeded only in 1985 in $\mathrm{Cu}$ and As. Although on the right bank of the Slovinský potok (brook) is the mining heap, the results of analysis of the sample point to below the limit values. This place has a relatively good isolation and from the body heap is not leaching the contaminants into the water flow.In the case of sample WSL3 we assume the lowest levels of heavy metals, as these are area in the upper basin, in a wooded area, above the former mining sites. These assumptions were confirmed in years 1985 and 2010, when there was not limit value is exceeded. An exception is the year 2011, when we recorded significant exceeded in $\mathrm{Cu}$, $\mathrm{Pb}$ and $\mathrm{Fe}$. This phenomenon we ascribe to the beginning of massive timber harvesting the forest just above the sample taken, which was greatly disturbed also the bed of the watercourse with the forestry machinery, thereby into the watercourse received heavy metals. For the samples WSL WSL 4 and 5, we recorded the exceedance in limits level by arsenic in year 1985. In these localities is already pollution of watercourse biological origin, as these are urban area Krompachy. Overall improvement in water quality sampling sites (except WSL1), originates by self-cleaning ability of water. In the case of soil samples (Table 2) were filled results expected in samples SSL1 and SSL5. This is the body of a sludge beds (pond) in the first case and in the second case it is the industrial heap. At both sites were stored sludges from mining and industrial operations, as well as 
slag. There were extremely exceeded values for all indicators in all years. Both locations are ecologically most risk sites in the region. Samples SSL3, and SSL4 SSL5 were sampled on agricultural land, particularly on pastures. For SSL3 measured values (with one exception) do not exceed the limit values. The site is surrounded by forests, under rock wall in the leeward position. In the case of the site SSL2 limit values were exceeded in $\mathrm{Cu}$ and $\mathrm{Cr}$ in 1985 and in the case of As in all three years. Place SSL4 located above the town of Krompachy, and is open to the wind flow from industrial operations in Krompachy with frequent dust fallout emission. Therefore, there are exceeded limit values in all studied elements except $\mathrm{Cu}$. Overall the measured values of heavy metals in soils are still extremely high, regardless of the sampling in all years. A slight improvement was seen in the case of As, which may be related to reducing discharges from the main the chimney works Kovohuty Krompachy, which contained most of the contaminants of As.

Table 1. The measured values of heavy metals in Slovinský potok (brook) $(\mu \mathrm{g} / \mathrm{l})$

\begin{tabular}{|c|c|c|c|c|c|c|c|c|c|}
\hline Locality & Year & $\mathbf{C u}$ & $\mathbf{A s}$ & $\mathbf{C d}$ & $\mathbf{P b}$ & $\mathbf{N i}$ & $\mathbf{C r}$ & $\mathbf{F e}$ & $\mathbf{C o}$ \\
\hline \hline \multirow{4}{*}{ WSL1 } & 1985 & $\mathbf{2 4}$ & $\mathbf{2 5 1}$ & 0,3 & 5 & 7 & 2 & 0,6 & 7 \\
\cline { 2 - 11 } & 2010 & 0,5 & $\mathbf{1 7 6}$ & 0,3 & 5 & 2 & 2 & 0,189 & 3 \\
\cline { 2 - 11 } & 2011 & 4 & $\mathbf{2 3 7}$ & 0,3 & $\mathbf{2 6}$ & 2 & 2 & 0,634 & 2 \\
\hline \multirow{4}{*}{ WSL2 } & 1985 & $\mathbf{3 0}$ & $\mathbf{2 2}$ & 0,4 & 5 & 13 & 2 & 0,6 & 7 \\
\cline { 2 - 11 } & 2010 & 3 & 3 & 0,3 & 5 & 2 & 2 & 0,059 & 2 \\
\cline { 2 - 11 } & 2011 & 6 & 3 & 0,3 & 5 & 2 & 2 & 0,059 & 2 \\
\hline \multirow{4}{*}{ WSL3 } & 1985 & 2 & 2 & 0,3 & 5 & 2 & 2 & 0 & 2 \\
\cline { 2 - 10 } & 2010 & 2 & 1 & 0,3 & 5 & 2 & 2 & 0,067 & 2 \\
\cline { 2 - 10 } & 2011 & $\mathbf{1 4 8}$ & 2 & 1,2 & $\mathbf{9 5}$ & 3 & 2 & $\mathbf{6 , 5 6}$ & 2 \\
\hline & 1985 & 18 & $\mathbf{3 3}$ & 0,3 & 5 & 6 & 2 & 0,1 & 3 \\
\cline { 2 - 10 } & 2010 & 3 & 14 & 0,3 & 5 & 2 & 2 & 0,092 & 3 \\
\cline { 2 - 10 } & 2011 & 7 & 13 & 0,3 & 5 & 2 & 2 & 0,085 & 2 \\
\hline \multirow{3}{*}{ WSL5 } & 1985 & 12 & $\mathbf{2 6}$ & 0,8 & 5 & 3 & 2 & 0 & 11 \\
\cline { 2 - 10 } & 2010 & 4 & 14 & 0,4 & 5 & 2 & 2 & 0,103 & 2 \\
\cline { 2 - 9 } & 2011 & 5 & 18 & 0,3 & 5 & 2 & 2 & 0,098 & 2 \\
\hline Limit value & & 20 & 20 & 1,5 & 20 & 20 & 50 & 2 & 50 \\
\hline
\end{tabular}

Table 2. The measured values of heavy metals in soils $(\mathrm{mg} / \mathrm{kg})$

\begin{tabular}{|c|c|c|c|c|c|c|c|c|c|}
\hline Locality & Year & $\mathbf{C u}$ & $\mathbf{A s}$ & $\mathbf{C d}$ & $\mathbf{P b}$ & $\mathbf{N i}$ & $\mathbf{C r}$ & Fe (\%) & Co \\
\hline \hline \multirow{4}{*}{ SSL1 } & 1985 & $\mathbf{1 4 4 2 0}$ & $\mathbf{5 7 0}$ & $\mathbf{2 , 1}$ & $\mathbf{6 2 8 7}$ & $\mathbf{7 4 1}$ & $\mathbf{6 5 2 5}$ & 22 & $\mathbf{4 8 7}$ \\
\cline { 2 - 10 } & 2010 & $\mathbf{1 1 0 0 8}$ & $\mathbf{4 8 2}$ & $\mathbf{1 , 5}$ & $\mathbf{5 2 2 4}$ & $\mathbf{6 2 7}$ & $\mathbf{4 9 5 5}$ & 28 & $\mathbf{3 7 7}$ \\
\cline { 2 - 10 } & 2011 & $\mathbf{1 0 7 9 0}$ & $\mathbf{4 5 8}$ & $\mathbf{1 , 5}$ & $\mathbf{5 7 9 1}$ & $\mathbf{6 2 4}$ & $\mathbf{5 1 2 1}$ & 26 & $\mathbf{3 4 9}$ \\
\hline \multirow{4}{*}{ SSL2 } & 1985 & $\mathbf{6 6}$ & $\mathbf{9 8}$ & 0,8 & 56 & 22 & $\mathbf{7 7}$ & 8 & 10 \\
\cline { 2 - 10 } & 2010 & 45 & $\mathbf{6 6}$ & $<0,5$ & 50 & 14 & 50 & 5 & 8 \\
\cline { 2 - 10 } & 2011 & 33 & $\mathbf{7 7}$ & $<0,5$ & 52 & 17 & 47 & 5 & 12 \\
\hline \multirow{4}{*}{ SSL3 } & 1985 & 19 & $\mathbf{2 8}$ & 0,6 & 12 & 11 & 15 & 4 & 11 \\
\cline { 2 - 10 } & 2010 & 10 & 15 & $<0,5$ & 8 & 8 & 22 & 3 & 8 \\
\cline { 2 - 10 } & 2011 & 12 & 17 & $<0,5$ & 5 & 15 & 19 & 3 & 6 \\
\hline \multirow{5}{*}{ SSL4 } & 1985 & 49 & $\mathbf{2 5 8}$ & $\mathbf{0 , 9}$ & $\mathbf{1 1 8}$ & $\mathbf{5 5}$ & $\mathbf{1 4 7}$ & 10 & $\mathbf{1 9}$ \\
\cline { 2 - 10 } & 2010 & 44 & $\mathbf{6 6}$ & $<0,5$ & $\mathbf{7 7}$ & 41 & $\mathbf{1 2 4}$ & 12 & $\mathbf{1 5}$ \\
\cline { 2 - 10 } & 2011 & 41 & $\mathbf{5 2}$ & $<0,5$ & 68 & $\mathbf{5 2}$ & $\mathbf{1 3 3}$ & 7 & $\mathbf{1 7}$ \\
\hline \multirow{3}{*}{ SSL5 } & 1985 & $\mathbf{7 5 2 8}$ & $\mathbf{8 5 2}$ & $\mathbf{1 , 5}$ & $\mathbf{7 8 8 7}$ & $\mathbf{4 5 2}$ & $\mathbf{4 8 0 9}$ & 12 & $\mathbf{1 2 8}$ \\
\cline { 2 - 9 } & 2010 & $\mathbf{6 5 2 8}$ & $\mathbf{7 5 5}$ & $\mathbf{1 , 0}$ & $\mathbf{7 9 0 4}$ & $\mathbf{6 5 8}$ & $\mathbf{4 2 8 7}$ & 22 & $\mathbf{2 0 7}$ \\
\hline
\end{tabular}




\begin{tabular}{|l|c|c|c|c|c|c|c|c|c|}
\hline & 2011 & $\mathbf{5 2 1 1}$ & $\mathbf{7 0 7}$ & $\mathbf{0 , 7}$ & $\mathbf{8 2 9 1}$ & $\mathbf{5 9 9}$ & $\mathbf{4 0 9 2}$ & 8 & $\mathbf{1 8 1}$ \\
\hline Limit value & & 60 & 25 & 0,7 & 70 & 50 & 70 & $?$ & 15 \\
\hline
\end{tabular}

\section{CONCLUSION}

Transformation of the landscape on the basis the impact of mining and industrial activities is a complex and long-term problem. Its effect lasts even after the cessation of mining and industrial activity. Environment investigated region was significantly burdened by heavy metals, especially mercury, arsenic, copper and iron. Here were the contaminated surface and underground waters, air, vegetation and soils. During of 25 years, we can say that there has been improvement in the quality of the environment, in particular air and water quality. Soil contamination by heavy metals is a long-term problem that requires a longer period of time and a lot of finance. The contamination of landscape spaces are manifested mainly in soils and river sediments, which have good sorption and storage properties.

Acknowlegments: This work was supported by project MŽP SR VEGA No 1/0159/15 and VEGA No 1/0008/13

\section{REFERENCES}

[1] ANGELOVIČOVÁ, L., BOGUSKÁ, Z. \& ČECH, V. Impact of mining activity of surface water quality and flora diversity. In: Növénytermelés: crop production, vol. 64, suppl. 4, Hungary, pp. 203-206, 2012. ISSN 0546-8191

[2] BANÁSOVÁ, V. Príspevok k zarastaniu medených háld v Slovinkách (Slovenské Rudohorie). In: Botanické práce, Bratislava, Slovakia, pp. 13-19, 1973.

[3] ČECH, V., KROKUSOVÁ, J. \& KUNÁKOVÁ, L. Odkalisko Slovinky pri Krompachoch: (geografické aspekty environmentálnej zát'aže). In: Folia geographica, vol. 17. Prešov: FHPV PU, Slovakia, pp. 64-81, 2011. ISSN 1336-6157

[4] ČECH, V., KUNÁKOVÁ, L. \& KROKUSOVÁ, J. Geoecological research methodology in the environmentally degraded landscape of the cadastral territory of the village Rudňany in Slovakia. 13th international multidisciplinary scientific geoconference SGEM 2013, Ecology, economics, education and legislation, Albena, Bulgaria, pp. 513-522, 2013. ISSN 1314-2704

[5] HRONEC, O., VILČEK, J., TÓTH, T., ANDREJOVSKÝ, P., ADAMIŠIN, P., ANDREJOVSKÁ, A., DAŇOVÁ, M., HUTTMANOVÁ, E., VILIMOVÁ, M., ŠKULTÉTY, P. \& JUHÁSZOVÁ, M. Ťažké kovy v pôdach a rastlinách v rudnianskogelnickej zat’aženej oblasti. In: Acta regionalia et environmentalica, vol. 5, no.1, Bratislava, Slovakia, pp.24-29, 2008. ISSN 1336-5452

[6] KROKUSOVÁ, J. Analýza priestorového rozmiestnenia banských antropogénnych foriem v obci Slovinky. In: Acta Facultatis Rerum Naturalium Universitatis Comenianae, Geographica, No. 3, Bratislava, Slovakia, pp. 300-308, 2005. ISBN 80-223-2144-3, ISSN 0231-715X

[7] KROKUSOVÁ, J. \& ČECH, V. Selected aspects of transformation process and environmental conditions of mining villages after the stoppage of mining activities (on the example of Rudňany and Slovinky). In: Globalization and crises in modern economy: the 1th Scientific volume, Klaipéda : Klaipéda University, Lithuania, pp. 108-113, 2010. ISBN 978-9955-18-507-9

[8] MICHAELI, E. BOLTIŽIAR, M., FAZEKAŠOVÁ, D., SOLÁR, V. 2013. The present character of the habitats on the industrial waste of lúženec in the Sered' (Slovak 
Republic). Journal of International Scientific Publications: Ecology and Safety, Volume 7, Part 1, p. 157-168, ISSN1313-2563.

http://www.scientific-publications.net/download/ecology-and-safety-2013-1.

[9] MŽP. Správa o stave životného prostredia Slovenskej republiky v roku 2009. MŽP SR, 110 p., 2009.

[10] ŠOTTNÍK, P., JURKOVIČ, L., VOZÁR, J. \& LALINSKÁ, B. Geochemical and mineralogical evaluation of Slovinky tailing impoundment material (Slovakia). 11th International Multidisciplinary Scientific GeoConference. SGEM 2011, Albena, Bulgaria, pp. 375-380, 2011. ISSN 1314-2704

[11] ZIMMERMANNOVÁ, K. Vysoké koncentrácie t’ažkých kovov v hubách v spišskom regióne. In: Enviromagazín, vol. 5, no. 2, Bratislava, Slovakia, pp. 30, 2000. 
International Scientific Conference GEOBALCANICA 2015 